$78 \mid 2020$

Cours LANSAD à distance en situation de crise sanitaire

\title{
Implementing an online English linguistics course during the Covid-19 emergency in Italy: Teacher's and students' perspectives
}

Mise en place d'un cours de linguistique anglaise en ligne pendant la crise de Covid-19 : le point de vue de l'enseignante et celui des étudiants

\section{Antonella Luporini}

\section{CpenEdition}

\section{Journals}

Electronic version

URL: http://journals.openedition.org/asp/6682

DOI: $10.4000 /$ asp.6682

ISSN: 2108-6354

\section{Publisher}

Groupe d'étude et de recherche en anglais de spécialité

\section{Printed version}

Date of publication: 1 November 2020

Number of pages: $75-88$

ISSN: 1246-8185

\section{Electronic reference}

Antonella Luporini, "Implementing an online English linguistics course during the Covid-19 emergency in Italy: Teacher's and students' perspectives", ASp [Online], 78 | 2020, Online since 01 November 2020, connection on 06 March 2021. URL: http://journals.openedition.org/asp/6682 ; DOI: https://doi.org/ 10.4000/asp.6682

This text was automatically generated on 6 March 2021

Tous droits réservés 


\title{
Implementing an online English linguistics course during the Covid-19 emergency in Italy: Teacher's and students' perspectives
}

\author{
Mise en place d'un cours de linguistique anglaise en ligne pendant la crise de \\ Covid-19: le point de vue de l'enseignante et celui des étudiants
}

\section{Antonella Luporini}

\section{Foreword}

1 Crises breed wide arrays of diversified reactions in human minds, ranging from utter dismay to a dogged determination to extract silver linings from the darkest clouds. In her paper, Antonella Luporini illustrates the latter disposition well. She explains how she promptly reorganised a BA's third-year ESP module to teach it online in reaction to the sudden Covid-19 lockdown that closed Italy's northern universities in spring 2020. Her report is both concise and detailed enough to understand the step-by-step decisions she made to ensure the successful completion of her teaching assignment while engaging her students to join in and take active part. Many western European university teachers were similarly confronted by the Covid crisis in early 2020 and our ASp readers will certainly find interesting insights in Luporini's testimony. They will also probably gain a sense of brotherly or sisterly empathy when the author develops trains of thought that we all shared when we faced the same digital issues in our efforts to keep our pedagogical shows on the road while lockdown shut us all in.

In my case, two remarks by the author stir instant familiarity. First, she observes that the University of Bologna already used a Moodle platform when Covid struck. That was the case at my university in Aix-Marseille, and I am quite sure most western European universities were in 
similar situations at the time. The implication is that many colleagues were not totally caught off guard by the crisis; in many faculties, it was just a case of accelerating the latent ongoing process of bringing teaching practices online and taking it to full completion. The bottom line, however, as Luporini realises, is that online tuition devours time to the point of totally redefining the calculation of teaching loads, which will give headaches to teachers' unions who are eager to defend their members' rights.

3 Second, she describes the low level of formality in her online exchanges with her students and her remark confirms the recurring feeling I have that the keyboard is a great equaliser. Even if some form of hierarchical emailing etiquette is kept between students and academics, I believe keyboard-mediated exchanges are largely anti-ex cathedra communication. From my own Covid experience, that tendency may have been increased by the sense of urgency shared both by teachers and learners when they felt they had to strive together to complete courses or exams to save the year. Luporini observes as much when she underlines (unusual) expressions of gratitude from students to teachers for the latter's determination to "safeguard teaching activities during the emergency" (section 3.). At the time, some form of "mission impossible" challenge braced us all towards priorities of action and evacuated unnecessary formalities. The sense of shared commitment may also explain the high and consistent levels of student attendance she registered during the module at Bologna, and may contrarily suggest that they are not to be taken for granted if online teaching is pursued in less dramatic circumstances.

As was to be expected, the author administered a questionnaire to collect student feedback. Doing without would have been odd and it is indeed highly instructive. Yet, I take it more as a snapshot of a highly specific situation than as a bearer of long-term lessons. For one thing, the IT landscape is changing so fast that responses may well fall into irrelevance when we return to the breach. For example, cheaper, more ubiquitous computing devices may rapidly close the "digital divide" highlighted by the paper, and soon make it a moot point among online teaching issues. Second, if digital training turns universal, upcoming generations of learners may steadily desert the "strongly disagree/disagree" columns as they may not even remember or imagine that alternative (e.g. face-to-face) teaching methods were once standard practice. As a result, to take stock of responses in a longer perspective, I would have added a more general question to the poll, even if its meaning sounds vague: "In your opinion, what is the more 'normal' teaching situation: online or face to face?" Repeating the question over the years would bring informative measures of students' evolving adherence to online tuition.

5 Many thanks to Antonella Luporini for her highly instructive and elaborate report: it provides us all with quality food for thought in these challenging times. (Michel Van der Yeught, AixMarseille University)

\section{Introduction}

6 This contribution reports on the experience of converting a face-to-face undergraduate English linguistics course into e-learning during the Covid-19-related lockdown at the University of Bologna, Italy: it takes stock of the teacher's perspective and the students' perceptions, collected via an ad hoc questionnaire.

7 The first case of Covid-19 on an Italian citizen was recorded on February 18, 2020, in Codogno, Lombardy. In a few days, the rapid increase in the number of new cases forced authorities to suspend face-to-face teaching, at all levels of education, in the North of Italy (so-called "red" and "yellow" zones) as of February 24. The same 
measures would soon be extended to the whole country, with a decree signed by the Prime Minister on March 4. Initially, there was uncertainty as to how long this exceptional situation would last; however, the constantly worsening infection rate soon made it clear that classrooms would remain empty for longer than expected.

One of the consequences of such an unprecedented scenario was an acceleration in the introduction of e-learning nationwide. This is notably one of the targets of the Digital Agenda for Europe, which Italy was struggling to meet before the health crisis, even if a transition to modern classroom education - with digital tools such as interactive whiteboards - had been put in place. The 2019 annual report on digital education in schools issued by the Italian Authority for Communications Guarantees (AGCOM 2019), re-elaborating data collected by the Ministry of Education in 2016-2017, shows an overall resistance towards e-learning, also linked to the unequal distribution of broadband network connections over the territory. According to the survey, only $47 \%$ of teachers made daily use of digital technologies in their activities; furthermore, most teachers resorted to digital technologies as a source of information, while only a minority habitually deployed online assessment methods and learning management systems. As for higher education, the offer of online courses was not homogeneous, varying greatly depending on the university/degree course (Formiconi 2016). However, due to the emergency, there was little or no time to carefully reconsider traditional teaching activities before they went online - an essential prerequisite for the successful implementation of e-learning (Govindasamy 2001). Other crucial issues raised by the sudden advent of virtual teaching concern home infrastructure (e.g. whether appropriate devices and sufficient bandwidth are available for teachers and students at home), and the need for specific training (Crawford et al. 2020). These could only be faced with ad hoc solutions and still need careful reflection.

\section{Context and learning outcomes}

This report focuses on the linguistics component of an "English language and linguistics" course taking place at the Department of Modern Languages, Literatures and Cultures. The course addresses third-year students enrolled in one of the undergraduate degree programmes available at the Department - Foreign languages and literature and Asian markets, languages and cultures - and is taught in English. Attenders are for the most part Italian students of English as a Foreign Language, in an age range between 20 and 25 years.

10 While the language component of the course is entrusted to certified mother tongue English teachers, aiming at a CEFR C1 level in all domains, the complementary linguistics curriculum revolves around the concept of register, in a contextual and English for Specific Purposes (ESP) perspective, adopting as course book Miller (2017). Building on notions of Systemic Functional Linguistics (SFL; Halliday \& Matthiessen 2004) imparted in the previous years, it aims to foster knowledge of the semantic/ lexico-grammatical features characterising different text-types in English, also in connection with the specific career options of the degree programmes: among the registers explored are the didactic, the procedural (e.g. technical instructions), the promotional (e.g. advertisements) and the informative (e.g. tourism texts). The curriculum includes both theory and practice. The theoretical part merges SFL with other complementary frameworks; the analytical toolkit thus developed is applied to 
the examination of different instances of register in the practical part. The linguistics component is spread over fifteen lessons, totalling thirty hours.

\section{Implementing the online course: methods}

11 In the academic year 2019-2020, the "English linguistics 3" course had been scheduled for the second semester, starting on February 10, with two lessons a week, held one after the other (with a break in between) on Mondays. Therefore, before the lockdown, I had met the students in person and taught the first four lessons face-to-face. These had consisted in a general introduction to the course and the SFL notion of register. During the first two weeks, the number of attenders had ranged between fifty and sixty. ${ }^{1}$ In the last week of February, lessons were cancelled and the University ICT unit started working on the infrastructure needed to ensure that activities would resume online as soon as possible. As a matter of fact, by March 4 more than $60 \%$ of the courses (approx. 2,100) had been reactivated in online mode, including mine.

Moodle was already in use at the University of Bologna before the Covid-19 pandemic: each course had its own page on the platform, to be organised by the teacher. Whether or how much this resource was deployed depended to a great extent on the teacher's familiarity with it and specific needs; I resorted to it mainly as a repository for the course materials, and to promote asynchronous discussion through an e-forum about the course topics. We needed, however, a videoconferencing platform to live broadcast lessons. The ICT team opted for Microsoft Teams, which met several essential requirements: it supported high numbers of simultaneous connections; it allowed screen sharing; it featured a chat; it guaranteed flexibility of access - by computer, tablet and smartphone, via a browser or an app. Indeed, numerous studies show that technology experience and accessibility are among the factors impacting on the success of an e-learning initiative (Williams van Rooij \& Zirkle 2016). Most videoconferencing systems currently used for educational purposes have the same features, or were optimised during the health crisis, but Teams had the additional advantage of being integrated into the Office 365 suite already available to university users. Thus, virtual classrooms were created on Teams and linked to the Moodle course pages, from where students accessed them directly. Students were informed about the new modalities using different channels, including the teachers' personal webpages, social media and the official newsletter.

13 If, on the one hand, thanks to the huge effort put in place by the University, I was able to resume the course after just a short break, on the other, there was little time to reflect carefully on how to redesign it with online pedagogy in mind. I decided to seize the opportunity to experiment with teaching methods that would replace so-called traditional lectures, focusing on how to maintain interactivity online.

Usually, in class, a lecture in the first slot would be followed, after the break, by textbased applications of the theory previously explained, with individual or group exercises plus discussion. With lessons going online, I reviewed the course plan removing the boundaries between theory and practice, whenever possible: (a) I foresaw a number of inductive lessons; (b) I introduced additional practice, mainly in the form of guided text analyses, and (c) I identified one topic to be experimentally introduced using "flipped classroom" methods, i.e. asking students to read pages from the course book and do research at home, and dedicating part of a subsequent lesson to a 
collaborative discussion. Even if this plan fit the remaining twenty-two hours on paper, in practice I realised that online lessons tended to be more time-consuming than faceto-face lessons, resulting in fewer topics covered, or fewer activities completed, in the same amount of time. In fact, I stopped more frequently to ask for feedback from the students, in the absence of those paralinguistic features I usually refer to in class; the students themselves tended to intervene more often. Therefore, I proposed adding two extra lessons at the end of the course, totalling twenty-six hours of e-learning instead of twenty-two; the students accepted. The final breakdown of the course is summarised in Table 1 below.

Table. Contents and format of online lessons

\begin{tabular}{|c|c|c|}
\hline $\begin{array}{l}\text { Lesson } \\
\text { no. }\end{array}$ & Contents & Lesson format \\
\hline 5 & $\begin{array}{l}\text { Continuum between closed (= less } \\
\text { open to variation) and open }(= \\
\text { more open to variation) registers }\end{array}$ & $\begin{array}{l}\text { INDUCTIVE - interactive explanation with discussion of } \\
\text { textual examples (e.g. air traffic control } \\
\text { communication; technical instructions; legal } \\
\text { documents; university lecture; narrative) }\end{array}$ \\
\hline 6 & $\begin{array}{l}\text { Continuum between closed and } \\
\text { open registers, cont. }\end{array}$ & PRACTICAL ACTIVITY - review exercises + discussion \\
\hline 7 & $\begin{array}{l}\text { Notions of intertextuality (Lemke } \\
\text { 1995) and contratextuality (Martin } \\
\text { 1986) }\end{array}$ & $\begin{array}{l}\text { INDUCTIVE - interactive explanation with discussion of } \\
\text { select examples from M.L. King's speeches (from } \\
\text { course book) }\end{array}$ \\
\hline 8 & $\begin{array}{l}\text { Notions of intertextuality and } \\
\text { contratextuality, cont. }\end{array}$ & $\begin{array}{l}\text { PRACTICAL ACTIVITY - guided analysis of Trump's July } \\
2016 \text { Nomination Acceptance Speech (from course } \\
\text { book) }\end{array}$ \\
\hline 9 & $\begin{array}{l}\text { Bakhtin's (1981) theory of } \\
\text { heteroglossia }\end{array}$ & LECTURE - Teacher's oral exposition \\
\hline 10 & $\begin{array}{l}\text { Jakobson's (1960) functions of } \\
\text { communication }\end{array}$ & $\begin{array}{l}\text { INDUCTIVE - interactive explanation with discussion of } \\
\text { textual examples (e.g. news report - referential } \\
\text { function; advertisement - conative function) }\end{array}$ \\
\hline 11 & $\begin{array}{l}\text { Jakobson's (1960) poetic function } \\
\text { and grammatical parallelism }\end{array}$ & LECTURE - Teacher's oral exposition \\
\hline 12 & $\begin{array}{l}\text { Poetic function and grammatical } \\
\text { parallelism, cont. }\end{array}$ & $\begin{array}{l}\text { PRACTICAL ACTIVITY - guided analysis of short texts in } \\
\text { terms of grammatical parallelism (a poem; an } \\
\text { advertisement; select excerpts from the Queen's } \\
\text { coronavirus speech) }\end{array}$ \\
\hline 13 & $\begin{array}{l}\text { The "special" register of literature } \\
\text { (Hasan 1985) }\end{array}$ & $\begin{array}{l}\text { LECTURE - Teacher's oral exposition } \\
\text { + FLIPPED PART A: home-study assignment }\end{array}$ \\
\hline 14 & $\begin{array}{l}\text { Bernstein's (1971) theory of coding } \\
\text { orientations }\end{array}$ & LECTURE - Teacher's oral exposition \\
\hline
\end{tabular}




\begin{tabular}{|l|l|l|}
\hline 15 & $\begin{array}{l}\text { The "special" register of literature, } \\
\text { cont. }\end{array}$ & $\begin{array}{l}\text { FLIPPED PART B: discussion of topics assigned as home- } \\
\text { study and question-time }\end{array}$ \\
\hline 16 & Text analysis & $\begin{array}{l}\text { PRACTICAL ACTIVITY - conclusive guided analysis of a } \\
\text { touristic/promotional text, applying the frameworks } \\
\text { explored throughout the course }\end{array}$ \\
\hline 17 & Mock exam & $\begin{array}{l}\text { PRACTICAL ACTIVITY - review exercises focusing on } \\
\text { exam preparation }\end{array}$ \\
\hline
\end{tabular}

As for the teaching materials, I continued using PowerPoint presentations, but adding hypertext (e.g. the activity on the Queen's coronavirus speech was linked to the related video on YouTube). After each lesson, the exercises done together and additional review exercises were uploaded to Moodle, also for the benefit of students who had not been able to attend.

\section{Post-course evaluation: teacher's perspective}

Weighing up the e-learning course as it was unfolding and after its conclusion, also in comparison with the face-to-face course, I identified several positive and negative aspects, briefly discussed below. All observations are based on my personal experience with both modalities.

The positive aspects fall within three main areas: attendance, interactivity and informality. Concerning the first point, the number of students taking part in the first e-lesson on March 4 was the same as in the pre-lockdown phase (50 to 60), and remained constant. This was an improvement in comparison with the face-to-face course, where attenders typically decrease from the first lesson onwards even by 20$25 \%$. The reasons may be varied and are not easy to ascertain. Probably the key factor is the time-saving nature of e-learning: normally, students have to spend even large amounts of time commuting, or moving between different buildings, to the extent that sometimes they are forced to make a choice as to what to attend. Real-time access to the lesson eliminates this problem, and is thus more efficient, also in terms of costs (especially for commuters).

Concerning the second point - interactivity - this too improved online, as noted in passing in Section 2. In class, probably due to the more formal and "prescribed" environment characterising lectures, students may be reluctant to interrupt the teacher's flow of discourse. On Teams, by contrast, they tended to be more interactive (i.e. more students interacted more frequently), also during lectures centred on the teacher's explanation. From this viewpoint, adopting teaching methods that would stimulate discussion (cf. Table 1) was a rewarding choice, even if it is worth noting that flipped classroom methods may initially meet with resistance from students who expect an expository approach from the teacher (probably more typical of the Italian academic context). There are, however, other reasons for this improvement. During the first e-lesson, we agreed that students would post questions and comments on the chat during lectures, not least because turn taking with so many participants would be problematic otherwise. I hypothesise that the decision to use the chat instead of the microphone goes a long way towards explaining the increase in interactivity, in line 
with studies showing the potential of instant messaging applications to promote interaction in online courses (Contreras-Castillo et al. 2007). Firstly, the students especially those in the age range 20-25 - feel comfortable and familiar with this medium, which they probably also perceive as less "intrusive" than oral questioning. Secondly, recalling that English is a foreign language for most students in this course, the possibility of writing instead of speaking may have functioned as an incentive. In fact, the group later converged around this choice: the chat became the channel of communication also for discussion and practical activities.

The overall less formal environment may also have helped the students feel more at ease. This brings me to the third point. Several studies show that computer-mediated communication may favour a sense of reduced distance: both social (e.g. Goertzen \& Kristjánsson 2007) and psychological (Oh et al. 2008). This was signalled in the chat by the use of emoticons and emojis: students would frequently react to their colleagues' or to my questions or comments with a "like" or a "love" symbol; in a few cases, even with an angry face, which was less easy to interpret (e.g. "we are wasting time on something that is clear to me"? Or, conversely, "I find this topic particularly problematic"?). Finally, attenders expressed their positive attitude by posting "Thank you" messages to the chat at the end of each lesson - something they wouldn't normally do when leaving the classroom. In fact, this may also be motivated by a feeling of gratitude towards their teachers and the institution, which several attenders expressed as personal communications, acknowledging the huge effort that had been put in place to safeguard teaching activities during the emergency.

Turning to the downsides, two aspects emerged as critical: a potential sense of isolation and the digital divide. The former was highlighted by the students themselves on several occasions. Our weekly lessons helped us save a semblance of our past routine in times of lockdown; however, at the same time, giving or attending a lesson in front of a screen brought with it a sense of isolation that was only partially counterbalanced by the liveliness of the chat. Online group activities may help solve this problem, and are in the to-do list should the course continue on Teams in future.

21 The latter aspect was less evident, and thus also more insidious. The digital divide is a national issue needing careful consideration, as it goes against a fundamental principle of e-learning, inclusivity. The term refers to inequality of access to the internet and computers. While the former aspect rightly attracts attention - a good connection is a sine qua non for any online activity - the latter should not be underestimated in the specific context of e-learning. Attending hours of online lessons using a tablet, or a smartphone, can lead to technical difficulties, besides being very tiring. Furthermore, faculty members have no way of knowing whether students have infrastructure problems unless they are told; yet, students may be reluctant to inform their teachers, perhaps also fearing social stigmatisation. In fact, this issue came to the fore only occasionally during the course, but it became more visible during the subsequent online exam session, as in this case the students were explicitly asked to report any problem linked to the device they were using or network connection.

\section{Post-course evaluation: students' perspective}

Recounting only my impressions would have meant telling only half the story. Therefore, at the end of the course I prepared an online anonymous questionnaire to 
collect the students' opinions. The questionnaire was drawn up using Google Forms and distributed through the chat linked to our Teams virtual classroom and the Moodle eforum. It was made clear to the students that questions concerned specifically our English linguistics course. Practically all the students welcomed the appeal: the form collected fifty-four responses in one week.

The questionnaire included four parts. Part 1 asked the students for basic information: degree programme, age and city from where they connected to the e-lessons. Part 2 delved into the specifics of the course, asking students whether they had attended the first classes at the Department before the lockdown; what kind of device they used at home, and whether they had missed one or more e-lessons. Part 3 was only available to respondents who had answered positively to the last question: it asked them to provide reasons by selecting one or more options from a checklist; it also contained an optional "other" box for further details. Part 4 concerned the main differences between classroom and e-learning. Students were asked to rate from 1 (strongly disagree) to 4 (strongly agree) the following assertions: (a) "e-lessons were more engaging"; (b) "elessons were easier to follow"; (c) "e-lessons were more interactive"; (d) "e-lessons were less formal"; (e) "I felt more at ease being at home"; (f) "my attention level was lower."

According to the answers in part 1 , most students are enrolled in the degree programme in foreign languages and literatures (79.6\%), are between 21 and 23 years old (87\%) and are based in Italy (98.1\%). More specifically, the majority (66.7\%) indicated a city from the Emilia-Romagna region. The other Italian regions mentioned were Lombardy, Veneto, Tuscany, Marche, Abruzzo, Puglia, Campania and Sicily; one respondent, perhaps an Erasmus student, said s/he had connected from France (Lyon). Thus, most students found themselves in Northern Italy - the area of the country that was most severely hit by Covid-19 - during the lockdown. In part 2, most respondents (77.8\%) declared to have come to class before the lockdown. This datum was important to ensure a more solid comparison with the elearning stage (part 4). Within the remaining $22.2 \%$, we probably find students who had problems attending face-to-face, but could join the course when it went online. As for the device, the overwhelming majority (92.6\%) selected "computer"; $5.6 \%$ chose "smartphone", and only $1.9 \%$, "tablet". This finding is in line with the observation made in Section 3: this aspect of the digital divide was not clear throughout the course. Answers to the question on attendance were more varied: $55.5 \%$ of students declared to have attended all e-lessons; $20.4 \%$, to have missed 1-2 lessons; $24.1 \%$ said they had missed 3 or more lessons.

The reasons given in part 3 by respondents who had missed one or more lessons (Figure 1) provided useful information complementing my perspective on the negative aspects. 
Figure 1. Answers to question: Why did you miss one or more online lessons?

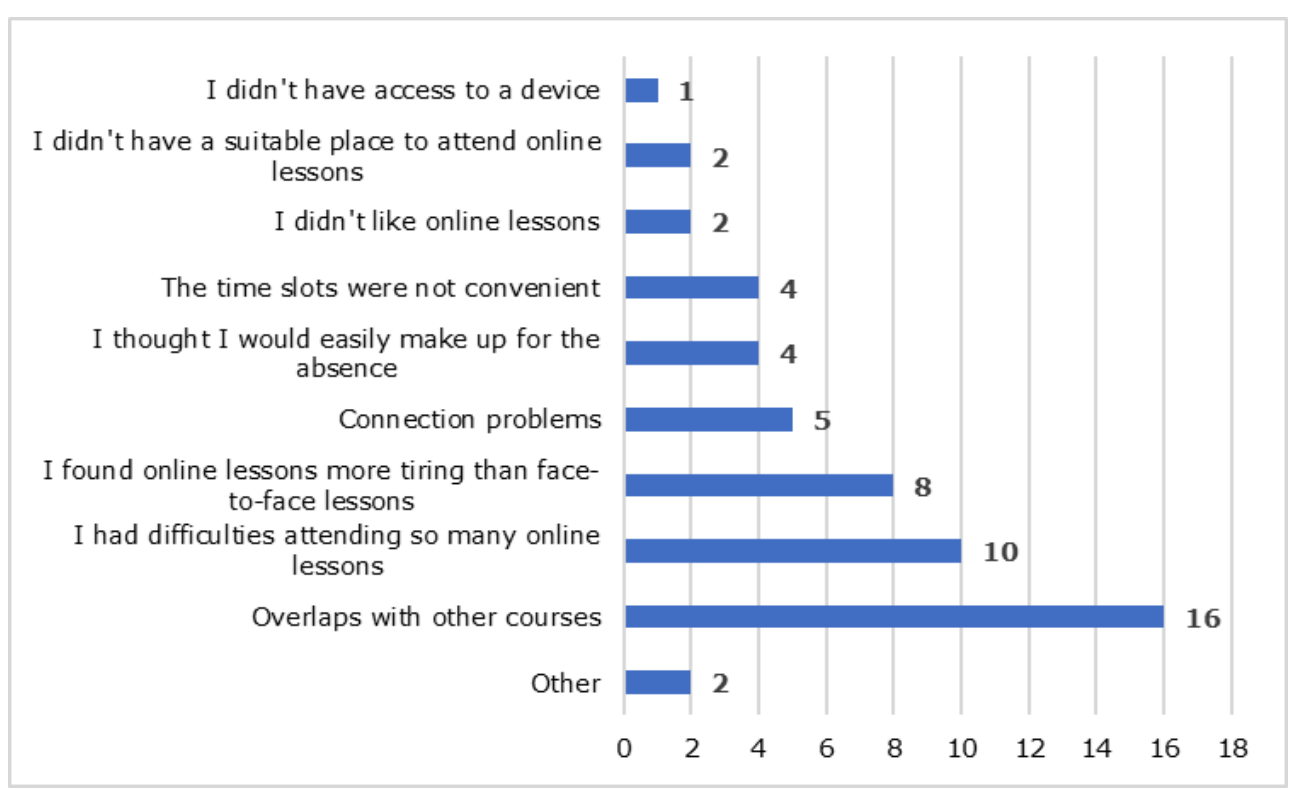

As can be noted, among the top options figure overlaps with other courses, difficulties attending many online lessons and also, linked to this, the fact that online lessons are perceived as being more tiring. While I was aware of the presence of timetable overlaps (a consequence of the wide range of courses offered in our degree programmes, which sometimes requires students to choose which courses to attend), the other reasons point to an aspect that I had not emphasised in my analysis: attending many online lessons may cause difficulties, also because e-learning (notwithstanding the device used) may be more tiring than classroom learning. Reasons broadly related to the digital divide (connection problems, no device available, but also lack of a suitable place) were chosen eight times in total, by eight respondents ( 5 ticked connection problems, 2 ticked lack of suitable place, one ticked no device). This shows again that the digital divide was an issue for some students, even if it had not always been explicitly raised before. Other reasons were selected fewer times; only two respondents, in particular, said that they didn't like online lessons. Both these questionnaires are consistently negative across the board: in part 4, these respondents said that they did not find online lessons more engaging, easier to follow, more interactive and more informal, and that they did not feel more at ease at home, while both evaluated their attention level online as lower. Positive attitude towards elearning seems to be a preliminary condition, whose absence may negatively impinge on all other aspects. Finally, the "other" box was filled in by two respondents, with circumstantial details ("I was studying for an exam"; "I had a call with another teacher”). Table 2 summarises the responses collected in part 4.

Table 2. Summary of responses to the statements in part 4

\begin{tabular}{|l|l|l|l|l|}
\hline Statement & Strongly disagree & Disagree & Agree & Strongly agree \\
\hline (a) E-lessons were more engaging & $11(20.4 \%)$ & $25(46.3 \%)$ & $14(25.9 \%)$ & $4(7.4 \%)$ \\
\hline (b) E-lessons were easier to follow & $6(11.1 \%)$ & $20(37 \%)$ & $20(37 \%)$ & $8(14.8 \%)$ \\
\hline
\end{tabular}




\begin{tabular}{|l|l|l|l|l|}
\hline (c) E-lessons were more interactive & $5(9.3 \%)$ & $18(33.3 \%)$ & $16(29.6 \%)$ & $15(27.8 \%)$ \\
\hline (d) E-lessons were less formal & $6(11.1 \%)$ & $16(29.6 \%)$ & $23(42.6 \%)$ & $9(16.7 \%)$ \\
\hline (e) I felt more at ease being at home & $4(7.4 \%)$ & $11(20.4 \%)$ & $24(44.4 \%)$ & $15(27.8 \%)$ \\
\hline (f) My attention level was lower & $8(14.8 \%)$ & $12(22.2 \%)$ & $14(25.9 \%)$ & $20(37 \%)$ \\
\hline
\end{tabular}
the nature of attention in the proposed activities (Kusik \& Sockett 2012). Crosschecking data, I noticed that all the students who had explained their absences saying that online lessons were more tiring, in part 3 (Figure 1), also positively rated the statement "my attention level was lower" (6 students, 75\%, strongly agreed; the remaining 2, 25\%, agreed). Furthermore, most respondents who evaluated their attention level as lower had also reacted negatively to the statements on engagement ( 25 out of $34,73.5 \%$ ) and easiness ( 21 out of $34,61.8 \%$ ); at the same time, however, only a minority of the same respondents had actually reacted negatively to the statements on interactivity (13 out of $34,38.2 \%$ ) and informality (11 out of $34,32.3 \%$ ). These data reinforce the view that interactivity and informality are not necessarily linked to 
engagement, easiness, and also attention: a good level of interactivity and an informal environment may help increase the effectiveness of an online course despite problems in the other dimensions, but they are not, in and of themselves, sufficient conditions.

\section{Conclusion}

By way of conclusion, I would like to summarise the main implications of this study.

It shows the importance of taking into account the learners' perspective in assessing the course performance.

It confirms the importance of carefully planning the course, since e-learning is not just a question of pushing a button (cf. Formiconi 2016). Even if the students' evaluation is mostly positive, probably the negative opinions emerging from the questionnaires are also a consequence of the rapid transition from a course created for face-to-face teaching to the online mode.

Concerning interactivity, data from this study suggest that we should pay special attention to students who decide not to interact online, who risk being invisible, and thus feeling isolated. Furthermore, interactive lessons or less formal lessons are not necessarily perceived as engaging. From this viewpoint, goal-directed tasks, group activities, flipped classroom methods and other forms of collaborative learning that foster a sense of online community should be given due space.

Finally, the timetable should be designed taking into account the risk of a lower attention level online and the consequences of the digital divide (not all students have $24 \mathrm{~h}$ connections, appropriate devices, or a quiet place to attend lessons). Breaks between consecutive lessons should be foreseen, and certain slots (e.g. lunch time) should ideally be avoided.

Online teaching during the Covid-19 health crisis - with its positive aspects, but also its limitations - was a testing ground and a learning experience for teachers as well as for students: one which should guide our reflection on these practices in the near future.

I would like to thank the students who attended my 2019-2020 "English linguistics 3" course for taking part in the questionnaire and providing me with so much food for thought.

\section{BIBLIOGRAPHY}

AGCOM. 2019. "Educare digitale. Lo stato di sviluppo della scuola digitale. Un sistema complesso ed integrato di risorse digitali abilitanti". Retrieved from <https://www.agcom.it/

documentazione/documento?

p_p_auth=fLw7zRht\&p_p_id=101_INSTANCE_FnOw5lVOIXoE\&p_p_lifecycle=0\&p_p_col_id=column-1\&p_p_col_count=1\&_101_INSTANC on $22 / 06 / 2020$.

BAKHTIN, Michail M. 1981. "Discourse in the novel”. In HOlQUIST, M. (Ed.), The Dialogic Imagination:

Four Essays by M.M. Bakhtin. Austin, TX: University of Texas Press, 259-422. 
BERNSTEIN, Basil. 1971. Class, Codes and Control. Theoretical Studies towards a Sociology of Language, volume 1. London: Routledge.

CONTRERAS-CAStillo, Juan, Carmen PÉREZ-Fragoso \& Jesus faVela. 2006. “Assessing the use of instant messaging in online learning environments”. Interactive Learning Environments 14/3, 205-218. DOI: $10.1080 / 10494820600853876$.

CRAWFORD, Joseph, Kerryn BUTLER-HENDERSON, Jürgen RUDOLPH, Bashar MALKAWI, Matt GLOWATZ, Rob BURTON, Paola MAGNI \& Sophia LAM. 2020. “COVID-19: 20 countries' higher education intra-period digital pedagogy responses". Journal of Applied Learning \& Teaching 3/1, 1-20. DOI: 10.37074/jalt. 2020.3.1.7.

FORMICONI, Andreas R. 2016. “La tortuosa via della didattica online nell'università". Studi sulla formazione 1, 105-132. DOI: 10.13128/Studi_Formaz-18564.

GOERTZEN, Phil \& Carolyn KRISTJÁNSSON. 2007. "Interpersonal dimensions of community in graduate online learning: Exploring social presence through the lens of Systemic Functional Linguistics". The Internet and Higher Education 10, 212-230. DOI: 10.1016/j.iheduc.2007.06.005.

GOVINDASAMY, Thavamalar. 2001. "Successful implementation of e-learning: Pedagogical considerations". The Internet and Higher Education 4, 287-299. DOI: 10.1016/S1096-7516(01)00071-9. HALLIDAY, Michael A.K. \& Christian M.I.M. MATTHIESSEN. 2004. An Introduction to Functional Grammar, $3^{\text {rd }}$ edition. London: Arnold.

HASAN, Ruqaiya. 1985. Linguistics, Language and Verbal Art. Geelong, Vic.: Deakin University Press. JAKOBSON, Roman. 1960. “Closing statement: Linguistics and poetics”. In SEBEOK, T.A. (Ed.), Style in Language. Cambridge, MA: MIT Press, 350-377.

KUSYK, Meryl \& Geoffrey SOCKETT. 2012. "From informal resource usage to incidental language acquisition: language uptake from online television viewing in English". ASp 62, 45-65. DOI: 10.4000/asp.3104.

LEMKE, Jay L. 1995. “Intertextuality and text semantics”. in FRIES, P. \& M. GREGORY (Eds.), Discourse in Society: Systemic Functional Perspectives. Norwood, N.J.: Ablex, 85-114.

MARTIN, James. 1986. “Grammaticalising ecology: The politics of baby seals and kangaroos”. In THREADGOLD T., E.A. GROSZ, G. KRESS \& M.A.K. HALLIDAY (Eds.), Language, Semiotics, Ideology. Sydney: Pathfinder Press, 225-267.

MILLER, Donna R. 2017. Language as Purposeful: Functional Varieties of Text, $2^{\text {nd }}$ edition. Bologna: AMS Acta Alma Digital Library. Available from <http://amsacta.unibo.it/5504/>.

OH, Hyelim, P. Curley SHAWn \& Mani R. SUBRAMANI. 2008. "The death of distance?: The influence of computer mediated communication on perceptions of distance". In Proceedings of the Twenty Ninth International Conference on Information Systems, 149-163.

WILLIAMS VAN ROOIJ, Shahron \& Kara ZIRKLE. 2001. "Balancing pedagogy, student readiness and accessibility: A case study in collaborative online course development". The Internet and Higher Education 28, 1-7. DOI: 10.1016/j.iheduc.2015.08.001.

\section{NOTES}

1. It should be noted that attendance is not obligatory in our degree programmes: hence the fluctuations in the number of students actually coming to class. 
2. Within the remaining $25 \%$ we find one student who did not find e-lessons more engaging, but found them easier (contrary to the reasons provided for his/her occasional absence), and one student who, conversely, found them more engaging, but harder to follow.

\section{INDEX}

Mots-clés: apprentissage en ligne, crise sanitaire, environnement informel, interaction en ligne, fracture numérique, linguistique anglaise, participation, seuil d'attention

Keywords: attendance, attention level, digital divide, e-learning, engagement, English linguistics, health crisis, informality, online interaction

\section{AUTHOR}

\section{ANTONELLA LUPORINI}

Antonella Luporini is a researcher with the University of Bologna. She holds a PhD in English Linguistics. Her research focuses on ESP (metaphor in financial discourse, language of art and cultural heritage), stylistics, and computer-mediated communication in EFL teaching. Her most recent publications include a book on crisis- and cryptocurrency-related metaphors and a chapter in an interdisciplinary volume on discourse analysis and austerity. antonella.luporini@unibo.it 